\title{
A Series of Coordination Polymers Constructed by 2-Phenylsuccinic Acid and Flexible Bis(imidazole) Ligands: Syntheses, Structures, and Photoluminescent Properties
}

Okan Zafer YEŞiLEL ( $\square$ yesilel@ogu.edu.tr)

Eskişehir Osmangazi University https://orcid.org/0000-0002-2284-1578

Umut Güler

Esengül Çiftçi

Mürsel Arıcı

\section{Research Article}

Keywords: Coordination polymer, 2-phenylsuccinate complex, bis((imidazol-1-yl)methyl)benzene complex, 2-phenylsuccinic acid

Posted Date: February 7th, 2022

DOI: https://doi.org/10.21203/rs.3.rs-1323932/v1

License: (9) This work is licensed under a Creative Commons Attribution 4.0 International License.

Read Full License

Version of Record: A version of this preprint was published at Journal of Molecular Structure on April 1st, 2022. See the published version at https://doi.org/10.1016/j.molstruc.2022.132991. 


\section{Abstract}

Eight coordination polymers (CPs), namely, [Co(m-phsuc)(m-obix) $]_{n}(1),\left\{\left[\mathrm{Co}_{2}\left(\mathrm{~m}\right.\right.\right.$-phsuc) ${ }_{2}(\mathrm{~m}-$ pbix $\left.\left.)_{1.5}\right] \times 2 \mathrm{H}_{2} \mathrm{O}\right\}_{\mathrm{n}}(2),\left[\mathrm{Zn}(\mathrm{m} \text {-phsuc) (m-obix) }]_{\mathrm{n}}(3),\left\{[\mathrm{Zn}(\mathrm{m}-\mathrm{phsuc})(\mathrm{m}-\mathrm{mbix})] \times \mathrm{H}_{2} \mathrm{O}\right\}_{\mathrm{n}}(4),\{[\mathrm{Zn}(\mathrm{m}-\mathrm{phsuc})(\mathrm{m}-\right.$ pbix) $\left.] \times \mathrm{H}_{2} \mathrm{O}\right\}_{\mathrm{n}}(5),\left\{[\mathrm{Zn}(\mathrm{m}-\mathrm{phsuc})(\mathrm{m} \text {-pbix })] \times 1.5 \mathrm{H}_{2} \mathrm{O} \times \mathrm{CH}_{3} \mathrm{OH}\right\}_{\mathrm{n}}(6),[\mathrm{Cd}(\mathrm{m}-\mathrm{phsuc})(\mathrm{m}-\mathrm{obix})]_{\mathrm{n}}(7)$ and $\left[\mathrm{Cd}\left(\mathrm{m}_{3}-\right.\right.$ phsuc)(m-pbix $\left.)_{0.5}\right]_{n}(8)\left(\right.$ phsucH $_{2}=$ 2-phenylsuccinic acid, obix = 1,2-bis((imidazol-1-yl)methyl)benzene, mbix = 1,3-bis ((imidazol-1-yl)methyl)benzene, pbix = 1,4-bis((imidazol-1-yl)methyl)benzene), were solvothermally synthesized and characterized by IR spectroscopy, elemental analysis, X-ray single-crystal diffraction, X-ray powder diffraction (PXRD), and thermal analyses. The structural analyses revealed that the compounds were 2D coordination polymers, in which metal ions were in tetrahedral coordination geometries in 1-6 and in octahedral coordination geometries in 2, 7 and $\mathbf{8}$. Compounds $\mathbf{1}, \mathbf{3}, \mathbf{4}, \mathbf{5}, \mathbf{7}$ and $\mathbf{8}$ displayed a 4-connected 2D wave sheets with the point symbol of $\left\{4^{4} \cdot 6^{2}\right\}$. Compound 2 was rare example exhibiting a 2D polyrotaxane structure. Compound 6 showed a 2D two-fold interpenetrating 3-connected hcb net with the point symbol of $\left\{6^{3}\right\}$. In the compounds, the neighboring $2 \mathrm{D}$ layers were further assembled by $\mathrm{p} \times \times \times \mathrm{p}$ stacking and weak $\mathrm{C}-\mathrm{H} \times \times \times \mathrm{p}$ interactions into the 3D supramolecular framework. The effects of the bis(imidazole) linkers and metals ions on the framework assemblies have been discussed. In addition, thermal and photoluminescent properties of the compounds were investigated.

\section{Introduction}

The design and construction of coordination polymers (CPs) have been drawn attention by researchers in the field of crystal engineering owing to their intriguing architectures and application areas such as gas adsorption, sensor, magnetism, luminescence, dye removal, etc [1-7]. In the construction of CPs with welldefined architecture, the selection of appropriate ligands is a useful strategy. However, in addition to metal ions and ligands, reaction conditions, the solvent can also affect the final structure of CPs $[8,9]$.

As known, rigid or flexible carboxylic acids have been widely utilized to provide charge balance of metal ions in the construction of CPs [10]. Especially; flexible ligands have been preferred to obtain an unpredicted structure with structural diversity $[11,12]$. Recently, the combination of flexible N-donor ligands and flexible dicarboxylic acids (the mixed ligand strategy) has been widely employed to build unexpected CPs with intriguing architectures $[13,14]$. In the literature, the coordination polymers synthesized with flexible dicarboxylic acids such as succinic acid, glutaric acid, adipic acid, etc, have been well documented and the ligands displayed several conformations to connect to metal ions resulting in versalite structures [15-19]. In our previous studies, we used glutaric acid and substitute glutaric acid with semi-flexible bis(imidazole) linkers in the synthesis of coordination polymers. They showed diverse coordination modes and conformations in the CPs with various dimensions [20-22]. In this study, 2-phenylsuccinic acid $\left(\right.$ phsucH $\left._{2}\right)$ containing phenyl side group, which was an asymmetric ligand, was used as an anionic linker. The phenyl side group on the succinate backbone can affect the coordination ability of the carboxylate group, orientation of the aliphatic skeleton, induce conformation ability, and reduce dimensionality in its compounds [23-25]. In the literature, some coordination polymers 
with phsucH $\mathrm{H}_{2}$ were synthesized and characterized [25-28]. However, there has been still need to investigate the effect of phenyl side group on succinate backbone on its compounds. Moreover, as an auxiliary ligand, we used semi-isomeric bis(imidazole) linker in the mixed-ligand assembly to investigate the effect of mixed ligand strategy on the dimensionality of phsuc ${ }^{2-}$ coordination polymers and also isomeric neutral ligands on the final structure of CPs. The imidazole rings of bis(imidazole) ligand around $-\mathrm{CH}_{2}-$ groups freely rotate to show various conformations, leading to interesting intriguing architecture [29].

In this context, eight coordination polymers, [Co( $\mu$-phsuc) $(\mu$-obix $)]_{n}(1),\left\{\left[\mathrm{Co}_{2}(\mu \text {-phsuc })_{2}(\mu-\text { pbix })_{1.5}\right] \cdot 2 \mathrm{H}_{2} \mathrm{O}\right\}_{n}$ (2), $\left[\mathrm{Zn}(\mu \text {-phsuc) }(\mu \text {-obix })]_{n}(3),\left\{[Z n(\mu-p h s u c)(\mu \text {-mbix })] \cdot \mathrm{H}_{2} O\right\}_{n}(4),\left\{[Z n(\mu-p h s u c)(\mu-p b i x)] \cdot H_{2} O\right\}_{n}(5),\{[Z n(\mu-\right.$ phsuc) $(\mu$-pbix $\left.)] \cdot 1.5 \mathrm{H}_{2} \mathrm{O} \cdot \mathrm{CH}_{3} \mathrm{OH}\right\}_{n}(6),[\mathrm{Cd}(\mu \text {-phsuc })(\mu \text {-obix })]_{n}(7)$ and $\left[\mathrm{Cd}\left(\mu_{3} \text {-phsuc }\right)(\mu \text {-pbix })_{0.5}\right]_{n}(8)$, with phsucH $\mathrm{H}_{2}$ and isomeric bis(imidazole) linkers in the presence of $\mathrm{Co}(\mathrm{II}), \mathrm{Zn}(\mathrm{II})$ and $\mathrm{Cd}(\mathrm{II})$ ions were hydrothermally synthesized and characterized by elemental analysis, IR spectroscopy, single crystal, and powder X-ray diffraction and thermal analysis.

\section{Materials And Methods}

\subsection{Materials and measurements}

All chemicals were received from commercial sources except that bis(imidazole) ligands were synthesized according to literature [29]. IR spectra in the range $4000-400 \mathrm{~cm}^{-1}$ were taken with a Bruker Tensor FT-IR spectrometer with the use of $\mathrm{KBr}$ pellet. Elemental analyses of the compounds for $\mathrm{C}, \mathrm{H}, \mathrm{N}$ were performed with a Perkin Elmer 2400 Series II device. A Perkin Elmer Diamond TG/DTA Thermal Analyzer were utilized to thermal analysis curves under a dry air atmosphere in the range $30-1000{ }^{\circ} \mathrm{C}$. Photoluminescence spectra of the compounds were gained with a Perkin-Elmer LS-55 spectrophotometer. A Panalytical Emperian X-ray diffractometer with $\mathrm{Cu}$-Ka radiation was used to record powder X-ray diffraction patterns. A Bruker Smart Apex II CCD diffractometer equipped with Mo-Ka radiation $(\lambda=$ $0.71073 \AA$ ) was used for single crystal X-ray diffraction data collection. SHELXT-2015 program in conjunction with the OLEX2 was used to solve the structures with direct methods and the structures were refined by full-matrix least-squares on all $\mathrm{F}^{2}$ data using SHELXL [30-32]. In the structures, all hydrogen atoms were calculated and refined using riding and free modes. The crystal structures were drawn using Mercury program [33]. ToposPro software was used for topological analyses of the compounds [34]. Table 1 shows the crystal data parameters and Tables S1-S4 indicate the selected bond distances, angles, and hydrogen bond geometries. 
Table 1

Crystal data and structure refinement parameters for compounds 1-4.

\begin{tabular}{|c|c|c|c|c|}
\hline & 1 & 2 & 3 & 4 \\
\hline Empirical formula & $\mathrm{C}_{24} \mathrm{H}_{22} \mathrm{CoN}_{4} \mathrm{O}_{4}$ & $\mathrm{C}_{82} \mathrm{H}_{82} \mathrm{Co}_{3} \mathrm{~N}_{12} \mathrm{O}_{20}$ & $\mathrm{C}_{24} \mathrm{H}_{22} \mathrm{~N}_{4} \mathrm{O}_{4} \mathrm{Zn}$ & $\mathrm{C}_{24} \mathrm{H}_{24} \mathrm{~N}_{4} \mathrm{O}_{5} \mathrm{Zn}$ \\
\hline $\begin{array}{l}\text { Formula weight } \\
\left(\mathrm{gmol}^{-1}\right)\end{array}$ & 489.38 & 1732.38 & 495.82 & 513.84 \\
\hline Diffractometer & $\begin{array}{l}\text { Bruker APEX II } \\
\text { CCD }\end{array}$ & $\begin{array}{l}\text { Bruker APEX II } \\
\text { CCD }\end{array}$ & $\begin{array}{l}\text { Bruker APEX II } \\
\text { CCD }\end{array}$ & $\begin{array}{l}\text { Bruker APEX II } \\
\text { CCD }\end{array}$ \\
\hline Rad. $/ \lambda(\AA)$ & Mo-K $\mathrm{K}_{\mathrm{a}} / 0.71073$ & Mo-K $\mathrm{K}_{\mathrm{a}} / 0.71073$ & Mo-K ${ }_{a} / 0.71073$ & Mo-K ${ }_{a} / 0.71073$ \\
\hline Temperature (K) & 293 & 293 & 293 & 293 \\
\hline Color & Violet & Violet & Colorless & Colorless \\
\hline Crystal system & Orthorhombic & Triclinic & Monoclinic & Monoclinic \\
\hline Space group & Pbca & $P-1$ & $P 2_{1} / \mathrm{n}$ & $P 2_{1} / \mathrm{c}$ \\
\hline $\mathrm{a}(\AA)$ & $14.5561(17)$ & $12.748(2)$ & $7.7463(10)$ & $11.297(2)$ \\
\hline $\mathrm{b}(\AA)$ & $16.342(2)$ & $12.962(3)$ & $17.386(2)$ & $16.368(4)$ \\
\hline$c(\AA)$ & $18.610(2)$ & $13.500(3)$ & $16.051(2)$ & $12.430(3)$ \\
\hline$a\left({ }^{\circ}\right)$ & 90 & $80.592(10)$ & 90 & 90 \\
\hline$\beta\left({ }^{\circ}\right)$ & 90 & $72.718(9)$ & $91.171(5)$ & $99.248(7)$ \\
\hline Y $\left({ }^{\circ}\right)$ & 90 & $72.326(9)$ & 90 & 90 \\
\hline$V\left(\AA^{3}\right)$ & $4427.0(9)$ & $2022.9(7)$ & $2161.3(5)$ & $2268.4(9)$ \\
\hline Z & 8 & 1 & 4 & 4 \\
\hline$D_{c}\left(g ~ c m^{-3}\right)$ & 1.469 & 1.422 & 1.524 & 1.505 \\
\hline$\mu\left(\mathrm{mm}^{-1}\right)$ & 0.82 & 0.69 & 1.18 & 1.13 \\
\hline$\theta$ range $\left(^{\circ}\right)$ & $2.9-28.4$ & $3.2-26.8$ & $2.9-28.4$ & $3.0-28.3$ \\
\hline Measured refls. & 106193 & 53440 & 65779 & 71545 \\
\hline Independent refls. & 5547 & 8139 & 5352 & 5659 \\
\hline $\mathrm{R}_{\text {int }}$ & 0.098 & 0.072 & 0.079 & 0.035 \\
\hline R1/wR2 & $0.124 / 0.228$ & $0.106 / 0.230$ & $0.130 / 0.271$ & $0.039 / 0.086$ \\
\hline$\Delta \rho_{\max } / \Delta \rho_{\min }\left(\mathrm{e} \AA^{-3}\right)$ & $0.75 /-0.68$ & $0.98 /-0.86$ & $1.99 /-1.19$ & $0.60 /-0.38$ \\
\hline
\end{tabular}




\begin{tabular}{|lllll|}
\hline & $\mathbf{1}$ & $\mathbf{2}$ & $\mathbf{3}$ & $\mathbf{4}$ \\
\hline $\mathbf{S}$ & 1.43 & 1.23 & 1.14 & 1.13 \\
\hline
\end{tabular}

Page 5/25 
Table 2

Crystal data and structure refinement parameters for complexes 5-8.

\begin{tabular}{|c|c|c|c|c|}
\hline & 5 & 6 & 7 & 8 \\
\hline Empirical formula & $\mathrm{C}_{24} \mathrm{H}_{23} \mathrm{~N}_{4} \mathrm{O}_{5} \mathrm{Zn}$ & $\mathrm{C}_{50} \mathrm{H}_{62} \mathrm{~N}_{8} \mathrm{O}_{15} \mathrm{Zn}_{2}$ & $\mathrm{C}_{24} \mathrm{H}_{22} \mathrm{CdN}_{4} \mathrm{O}_{4}$ & $\mathrm{C}_{17} \mathrm{H}_{15} \mathrm{CdN}_{2} \mathrm{O}_{4}$ \\
\hline $\begin{array}{l}\text { Formula weight } \\
\left(\mathrm{gmol}^{-1}\right)\end{array}$ & 510.82 & 1135.73 & 542.82 & 423.71 \\
\hline Diffractometer & $\begin{array}{l}\text { Bruker APEX II } \\
\text { CCD }\end{array}$ & $\begin{array}{l}\text { Bruker APEX II } \\
\text { CCD }\end{array}$ & $\begin{array}{l}\text { Bruker APEX II } \\
\text { CCD }\end{array}$ & $\begin{array}{l}\text { Bruker APEX II } \\
\text { CCD }\end{array}$ \\
\hline Rad. $/ \lambda(\AA)$ & Mo-K $\mathrm{K}_{\mathrm{a}} / 0.71073$ & Mo-K $\mathrm{K}_{\mathrm{a}} / 0.71073$ & Mo-K $\mathrm{K}_{\mathrm{a}} / 0.71073$ & Mo-K ${ }_{a} / 0.71073$ \\
\hline Temperature (K) & 293 & 293 & 293 & 293 \\
\hline Color & Colorless & Colorless & Colorless & Colorless \\
\hline Crystal system & Monoclinic & Monoclinic & Monoclinic & Triclinic \\
\hline Space group & $P 2_{1} / \mathrm{n}$ & $C 2 / \mathrm{c}$ & $P 2_{1} / \mathrm{n}$ & $P 2_{1} / \mathrm{n}$ \\
\hline $\mathrm{a}(\AA)$ & $12.0883(12)$ & $23.450(3)$ & $7.5704(6)$ & $6.8249(8)$ \\
\hline $\mathrm{b}(\AA)$ & $16.1314(17)$ & $13.7109(15)$ & $17.6491(15)$ & $10.6963(12)$ \\
\hline$c(\AA)$ & $13.1076(13)$ & $17.524(2)$ & $16.6555(15)$ & $11.0880(13)$ \\
\hline$a\left({ }^{\circ}\right)$ & 90 & 90 & 90 & $94.735(4)$ \\
\hline$\beta\left({ }^{0}\right)$ & $114.208(4)$ & $91.838(5)$ & $93.127(3)$ & $92.701(4)$ \\
\hline Y $\left({ }^{\circ}\right)$ & 90 & 90 & 90 & $93.412(4)$ \\
\hline$V\left(\AA^{3}\right)$ & $2331.2(4)$ & $5631.4(12)$ & $2222.0(3)$ & $804.14(16)$ \\
\hline Z & 4 & 4 & 4 & 2 \\
\hline$D_{c}\left(\mathrm{~g} \mathrm{~cm}^{-3}\right)$ & 1.455 & 1.340 & 1.623 & 1.750 \\
\hline$\mu\left(\mathrm{mm}^{-1}\right)$ & 1.10 & 0.92 & 1.02 & 1.38 \\
\hline$\theta$ range $\left(^{\circ}\right)$ & $3.0-28.3$ & $2.9-26.5$ & $3.1-26.4$ & $3.0-28.4$ \\
\hline Measured refls. & 75188 & 61332 & 58628 & 33460 \\
\hline Independent refls. & 5752 & 5726 & 4533 & 3959 \\
\hline$R_{\text {int }}$ & 0.052 & 0.069 & 0.047 & 0.030 \\
\hline R1/wR2 & $0.094 / 0.222$ & $0.150 / 0.121$ & $0.052 / 0.107$ & $0.043 / 0.113$ \\
\hline$\Delta \rho_{\max } / \Delta \rho_{\min }\left(\mathrm{e}^{-3}\right)$ & $1.78 /-1.23$ & $1.76 /-1.53$ & $1.14 /-0.91$ & $1.62 /-0.89$ \\
\hline
\end{tabular}




\begin{tabular}{|lllll|}
\hline & $\mathbf{5}$ & $\mathbf{6}$ & $\mathbf{7}$ & $\mathbf{8}$ \\
\hline $\mathbf{S}$ & 1.07 & 1.22 & 1.26 & 1.26 \\
\hline
\end{tabular}

\subsection{Syntheses of the compounds}

\section{$[\text { Co( }(\mu \text {-phsuc })(\mu \text {-obix })]_{n}(1)$}

A mixture of $\mathrm{Co}\left(\mathrm{NO}_{3}\right)_{2} \cdot 6 \mathrm{H}_{2} \mathrm{O}(0.29 \mathrm{~g}, 1 \mathrm{mmol})$, phsuch $2(0.194 \mathrm{~g}, 1 \mathrm{mmol})$ and obix $(0.240 \mathrm{~g}, 1 \mathrm{mmol})$ was stirred at room temperature for $30 \mathrm{~min}$ in $30 \mathrm{~mL}$ distilled water. $6.0 \mathrm{M} \mathrm{HNO}_{3}$ (3 drops) was added dropwise into the mixture to obtain a clear solution. Then the clear solution was placed in a $45 \mathrm{~mL}$ Teflonlined stainless steel vessel and heated at $120^{\circ} \mathrm{C}$ for 3 days. After cooling to room temperature, the clear solution was waited about 20 days to obtain violet crystals were obtained. FT-IR $\left(\mathrm{KBr}, \mathrm{cm}^{-1}\right): 3433(\mathrm{w})$, 3116(m), 2962(w), 2893(w), 1612(vs), $1521(\mathrm{~m}), 1373(\mathrm{~s}), 1298(\mathrm{~m}), 1244(\mathrm{~m}), 1109(\mathrm{~m}), 966(\mathrm{~m}), 843(\mathrm{~m})$, 742(m), 655(m). Anal. calcd (\%) for $\mathrm{C}_{24} \mathrm{H}_{22} \mathrm{~N}_{4} \mathrm{O}_{4} \mathrm{Co}(489.40 \mathrm{~g} / \mathrm{mol})$ : $\mathrm{C}, 58.90 ; \mathrm{H}, 4.53 ; \mathrm{N}, 11.45$. Found: $\mathrm{C}$, $58.92 ; \mathrm{H}, 4.33 ; \mathrm{N}, 11.59$.

\section{$\left\{\left[\mathrm{Co}_{2}(\mu-\text { phsuc })_{2}(\mu-\text { pbix })_{1.5}\right] \cdot 2 \mathrm{H}_{2} \mathrm{O}\right\}_{n}(2)$}

A mixture of $\mathrm{Co}\left(\mathrm{CH}_{3} \mathrm{COO}\right)_{2} \cdot 4 \mathrm{H}_{2} \mathrm{O}(0.25 \mathrm{~g}, 1 \mathrm{mmol})$, phsuch $2(0.194 \mathrm{~g}, 1 \mathrm{mmol})$ and pbix $(0.240 \mathrm{~g}, 1 \mathrm{mmol})$ was stirred at room temperature for $30 \mathrm{~min}$ in $15 \mathrm{~mL}$ distilled water. The solution was placed in a $25 \mathrm{~mL}$ closed capped bottle and and heated at $120^{\circ} \mathrm{C}$ for 3 days. Upon cooling to room temperature, violet crystals were obtained. FT-IR (KBr, cm$\left.{ }^{-1}\right)$ : 3429(s), 3134(s), 3028(w), 1616(vs), 1585(s), 1520(s), 1381 (s), 1232(m), 1087(m), 992(m), 903(m), 842(m). Anal. calcd (\%) for $\mathrm{C}_{41} \mathrm{H}_{41} \mathrm{~N}_{6} \mathrm{O}_{10} \mathrm{Co}_{2}(895.70 \mathrm{~g} / \mathrm{mol})$ : $\mathrm{C}$, $54.98 ; H, 4.61 ; N, 9.38$. Found: $C, 54.88 ; H, 4.63 ; N, 9.44$.

\section{$[\mathrm{Zn}(\mu-\mathrm{phsuc})(\mu \text {-obix })]_{\mathrm{n}}(3)$}

The complex was prepared in a similar manner as 1 except for the use of $\mathrm{Zn}\left(\mathrm{NO}_{3}\right)_{2} \cdot 6 \mathrm{H}_{2} \mathrm{O}(0.297 \mathrm{~g}, 1$ mmol) instead of $\mathrm{Co}\left(\mathrm{NO}_{3}\right)_{2} \cdot 6 \mathrm{H}_{2} \mathrm{O}$. Colorless crystals of 3 were obtained. $\mathrm{FT}-\mathrm{IR}\left(\mathrm{KBr}, \mathrm{cm}^{-1}\right)$ : $3433(\mathrm{~s})$, 3116(s), 2963(w), 2893(w), 1612(vs), 1522(s), 1373(s), $1109(\mathrm{~s}), 953(\mathrm{~m}), 891(\mathrm{~m}), 844(\mathrm{~m}), 742(\mathrm{~m})$, 656(m). Anal. calcd (\%) for $\mathrm{C}_{24} \mathrm{H}_{22} \mathrm{~N}_{4} \mathrm{O}_{4} \mathrm{Zn}(495.80 \mathrm{~g} / \mathrm{mol})$ : C, 58.14; $\mathrm{H}, 4.47 ; \mathrm{N}, 11.30$. Found: $\mathrm{C}, 58.23 ; \mathrm{H}$, $4.45 ; \mathrm{N}, 11.33$.

\section{$\{\{$ Zn( $\mu$-phsuc $)(\mu-$ mbix $\left.)] \cdot H_{2} O\right\}_{n}(4)$}

A mixture of $\mathrm{Zn}\left(\mathrm{NO}_{3}\right)_{2} \cdot 6 \mathrm{H}_{2} \mathrm{O}(0.297 \mathrm{~g}, 1 \mathrm{mmol})$, phsuch $2(0.194 \mathrm{~g}, 1 \mathrm{mmol})$, mbix $(0.240 \mathrm{~g}, 1 \mathrm{mmol})$ and $\mathrm{NaOH}(0.080 \mathrm{~g}, 2 \mathrm{mmol})$ were dissolved in solution of $\mathrm{H}_{2} \mathrm{O}(15 \mathrm{~mL})$, DMF $(1 \mathrm{~mL})$ and $\mathrm{CH}_{3} \mathrm{OH}(1 \mathrm{~mL})$. Precipitation formed after stirring the mixture for $30 \mathrm{~min}$ and then the mixture was placed in a $25 \mathrm{~mL}$ closed capped bottle and heated at $120^{\circ} \mathrm{C}$ for 3 days. Upon cooling to room temperature, colorless crystals were obtained. FT-IR (KBr, cm $\left.{ }^{-1}\right)$ : 3522(s), 3408(s), 3126(s), 3087(w), 3051(w), 2922(w), 1606(vs), 1598(vs), $1511(\mathrm{~m}), 1402(\mathrm{vs}), 1306(\mathrm{w}), 1221(\mathrm{~m}), 1090(\mathrm{~m}), 1022(\mathrm{~m}), 952(\mathrm{~m}), 873(\mathrm{~m}), 743(\mathrm{~m}), 657(\mathrm{~m})$. 
Anal. calcd (\%) for $\mathrm{C}_{24} \mathrm{H}_{22} \mathrm{~N}_{4} \mathrm{O}_{4} \mathrm{Zn}(513.90 \mathrm{~g} / \mathrm{mol})$ : C, 56.10; $\mathrm{H}, 4.71 ; \mathrm{N}, 10.90$. Found: $\mathrm{C}, 55.98 ; \mathrm{H}, 4.93 ; \mathrm{N}$, 11.03.

\section{$\left\{[Z n(\mu-p h s u c)(\mu-p b i x)] \cdot H_{2} O\right\}_{n}(5)$}

A mixture of $\mathrm{Zn}\left(\mathrm{CH}_{3} \mathrm{COO}\right)_{2} \cdot 2 \mathrm{H}_{2} \mathrm{O}(0.249 \mathrm{~g}, 1 \mathrm{mmol})$, phsucH ${ }_{2}(0.194 \mathrm{~g}, 1 \mathrm{mmol})$, pbix $(0.240 \mathrm{~g}, 1 \mathrm{mmol})$ and $\mathrm{NaOH}(0.35 \mathrm{~mL}, 0.65 \mathrm{M})$ were dissolved in solution of $\mathrm{H}_{2} \mathrm{O}(30 \mathrm{~mL})$ and $\mathrm{C}_{2} \mathrm{H}_{5} \mathrm{OH}(3.5 \mathrm{~mL})$. Precipitation formed after stirring the mixture for $30 \mathrm{~min}$ and then the mixture was placed in a $45 \mathrm{~mL}$ Teflon-lined stainless steel vessel and heated at $140{ }^{\circ} \mathrm{C}$ for 3 days. Upon cooling to room temperature, colorless crystals were obtained. FT-IR (KBr, cm$\left.{ }^{-1}\right)$ : 3508(s), 3500(s), 3124(s), 2984(w), 1604(vs), 1598(vs), 1522(m), 1389(s), 1359(s), 1223(m), 1097(s), 1022(w), 955(m), 894(w), 788(m), 657(m). Anal. calcd (\%) for $\mathrm{C}_{24} \mathrm{H}_{24} \mathrm{~N}_{4} \mathrm{O}_{5} \mathrm{Zn}(513.90 \mathrm{~g} / \mathrm{mol})$ : C, 56.10; $\mathrm{H}, 4.71 ; \mathrm{N}, 10.90$. Found: C, 56.18; H, 4.54; N, 10.92.

\section{$\left\{[Z n(\mu-p h s u c)(\mu-p b i x)] \cdot 1.5 \mathrm{H}_{2} \mathrm{O} \cdot \mathrm{CH}_{3} \mathrm{OH}\right\}_{n}(6)$}

A mixture of $\mathrm{Zn}\left(\mathrm{CH}_{3} \mathrm{COO}\right)_{2} \cdot 2 \mathrm{H}_{2} \mathrm{O}(0.249 \mathrm{~g}, 1 \mathrm{mmol})$, phsuch $\mathrm{H}_{2}(0.194 \mathrm{~g}, 1 \mathrm{mmol})$, pbix $(0.240 \mathrm{~g}, 1 \mathrm{mmol})$ and $\mathrm{NaOH}(0.080 \mathrm{~g}, 2 \mathrm{mmol})$ were dissolved in solution of $\mathrm{H}_{2} \mathrm{O}(5 \mathrm{~mL})$, DMF $(5 \mathrm{~mL})$ and $\mathrm{CH}_{3} \mathrm{OH}(5 \mathrm{~mL})$. This mixture was stirred for $30 \mathrm{~min}$ and then transferred to a $25 \mathrm{~mL}$ Teflon-lined stainless steel vessel, heated to $140^{\circ} \mathrm{C}$ for 3 days, After slow cooling to room temperature, colorless crystals of 6 were obtained. FT-IR (KBr, cm $\left.{ }^{-1}\right)$ : 3441(s), 3134(w), 2968(w), 1610(vs), 1525(m), 1373(s), $1251(\mathrm{~m}), 1090(\mathrm{~m}), 963(\mathrm{~m})$, 857(w), 754(m), $656(\mathrm{~m})$. Anal. calcd (\%) for $\mathrm{C}_{25} \mathrm{H}_{32} \mathrm{~N}_{4} \mathrm{O}_{8} \mathrm{Zn}(581.90 \mathrm{~g} / \mathrm{mol}): \mathrm{C}, 51.60 ; \mathrm{H}, 5.54 ; \mathrm{N}, 9.63$. Found: C, 51.18; $H, 5.34 ; N, 9.43$.

\section{$[\mathrm{Cd}(\mu \text {-phsuc })(\mu \text {-obix })]_{n}(7)$}

The compound was obtained in a similar method to that of 1 except for the use of $3 \mathrm{CdSO}_{4} \cdot 8 \mathrm{H}_{2} \mathrm{O}(0.256$ $\mathrm{g}, 1 \mathrm{mmol})$ instead of $\mathrm{Co}\left(\mathrm{NO}_{3}\right)_{2} \cdot 6 \mathrm{H}_{2} \mathrm{O}$. Colorless crystals of 7 were obtained. FT-IR $\left(\mathrm{KBr}, \mathrm{cm}^{-1}\right): 3444(\mathrm{w})$, 3122(m), 3020(w), 2974(w), 1572(vs), 1519(s), $1410(\mathrm{vs}), 1291(\mathrm{~m}), 1242(\mathrm{~m}), 1085(\mathrm{~s}), 927(\mathrm{~m}), 873(\mathrm{~m})$, $831(\mathrm{~m}), 742(\mathrm{~s}), 653(\mathrm{~m})$. Anal. calcd (\%) for $\mathrm{C}_{24} \mathrm{H}_{22} \mathrm{~N}_{4} \mathrm{O}_{4} \mathrm{Cd}(542.90 \mathrm{~g} / \mathrm{mol})$ : C, 53.10; $\mathrm{H}, 4.08 ; \mathrm{N}, 10.32$. Found: C, 53.03; $H, 4.14 ; \mathrm{N}, 10.09$.

\section{$\left[C d\left(\mu_{3}-\text { phsuc }\right)(\mu-p b i x)_{0.5}\right]_{n}(8)$}

A mixture of $3 \mathrm{CdSO}_{4} \cdot 8 \mathrm{H}_{2} \mathrm{O}(0.256 \mathrm{~g}, 1 \mathrm{mmol})$, phsucH $2(0.194 \mathrm{~g}, 1 \mathrm{mmol})$ and pbix $(0.240 \mathrm{~g}, 1 \mathrm{mmol})$ was stirred at room temperature for $30 \mathrm{~min}$ in $30 \mathrm{~mL}$ distilled water. The solution was transferred in a $45 \mathrm{~mL}$ Teflon-lined stainless steel vessel and heated at $120^{\circ} \mathrm{C}$ for 3 days. Upon cooling to room temperature, violet crystals were obtained. FT-IR $\left(\mathrm{KBr}^{\mathrm{cm}} \mathrm{cm}^{-1}\right): 3502(\mathrm{~m}), 3420(\mathrm{~m}), 3109(\mathrm{~m}), 3030(\mathrm{w}), 2988(\mathrm{w}), 1560(\mathrm{vs})$, 1419(s), 1298(w), 1095(m), 998(m), 942(m), 897(w), 735(m), 658(m). Anal. calcd (\%) for $\mathrm{C}_{17} \mathrm{H}_{15} \mathrm{~N}_{2} \mathrm{O}_{4} \mathrm{Cd}$ (423.75 g/mol): C, 48.19; H, 3.57; N, 6.61. Found: C, 48.22; H, 3.71; N, 6.49.

\section{Results And Discussion}




\subsection{Syntheses and Characterizations}

The eight coordination polymers were hydrothermally synthesized with phsucH $\mathrm{H}_{2}$ and isomeric bis(imidazole) linkers in the presence of diverse metal ions and characterized with several techniques. Compound 1 was not reproduced repeatedly. Hence, only single crystal analysis result was given to determine the effect of isomeric bis(imidazole) linkers on the structure. Elemental analysis results are agreed with the given formulations. IR spectra of compounds 2, 4-6 indicate that the broad bands observed at about $3429 \mathrm{~cm}^{-1}$ are attributed to the $\mathrm{v}(\mathrm{OH})$ stretchings of crystal water molecules. The aromatic and aliphatic $\mathrm{v}(\mathrm{CH})$ stretchings appeared at between 3134 and $2922 \mathrm{~cm}^{-1}$ in all compounds. In the compounds, asymmetric $\left(\mathrm{v}_{\mathrm{as}} \mathrm{COO}^{-}\right)$and symmetric $\left(\mathrm{v}_{\mathrm{s}} \mathrm{COO}^{-}\right)$stretching vibrations of carboxylate groups of phsuc ${ }^{2-}$ are observed in the range of $1616-1560 \mathrm{~cm}^{-1}$ and $1419-1359 \mathrm{~cm}^{-1}$, respectively. The asymmetric stretching vibration of $\mathrm{phsucH}_{2}$ shifts to a lower frequency after connecting to metal ions (Figs. S1-S8). Moreover, $\mathrm{v}(\mathrm{C}=\mathrm{N})$ stretching vibrations of imidazole rings are observed at $1520 \mathrm{~cm}^{-1}$ in the compounds.

Descriptions of crystal structures

[Co( $\mu$-phsuc)( $\mu$-obix $)]_{n}(1) . X$-ray crystallographic analysis indicates that compound 1 crystallizes in the orthorhombic Pbca space group, and the asymmetric unit of 1 contains one Co(II) ion, one phsuc and one obix ligand (Fig. 1a). Co1 ion is in a slightly distorted tetrahedral coordination geometry with two nitrogen atoms from two different obix ligands and two oxygen atoms from two different phsuc ligands. Each phsuc ligand adopts bis(monodentate) coordination mode linking $\mathrm{Co}$ (II) ions leading to a 1D linear chain with the intrachain Co...Co distance $7.546 \AA$ (Fig. 1b). Furthermore, the adjacent 1D chains are connected by obix ligands into a 2D wave network (Fig. 1C.). This 2D network can be clarified as a 4-connected sql/Shubnikov tetragonal topology with the point symbol of $\left\{4^{4} \cdot 6^{2}\right\}$ (Fig. 1d).

$\left\{\left[\mathrm{CO}_{2}(\mu \text {-phsuc })_{2}(\mu \text {-pbix })_{1.5}\right] \cdot 2 \mathrm{H}_{2} \mathrm{O}\right\}_{n}(2)$. Compound 2 crystallizes in the triclinic system, $P-1$ space group. The asymmetric unit of 2 contains two independent $\mathrm{Co}(\mathrm{II})$ ions, two phsuc, one and a half pbix ligands and two crystal water molecules. As shown in Fig. 2a, there are two cobalt centres (Co1 and Co2) in the compound with different coordination environments. Co1 is coordinated to two pbix ligands via two nitrogen atoms of the imidazole groups and two oxygen atoms of two carboxylate groups from two different phsuc ligands, showing a distorted tetrahedral geometry. Whereas, $\mathrm{Co} 2$ is six-coordinated with four carboxylate oxygen atoms from four different phsuc ligands to form a distorted octahedral geometry with $\mathrm{N}_{2} \mathrm{O}_{4}$ donor set. The basal plane is constructed by the coordination of four carboxylate oxygen atoms, whereas, the axial site of $\mathrm{Co} 2$ ion is occupied by two nitrogen atoms from two symmetry-related pbix ligands. The carboxylate groups of phsuc ligands are completely deprotonated and adopt the bis(monodentate) coordination modes. Co1 and Co2 are bridged by phsuc anions into a 1D double chain with four metallic 28-member rings (Fig. 2b). Then, the adjacent two 1D double chains are further connected by two nitrogen atoms from pbix ligands with bimetallic 26-member rings, thus generating a 2D tubular structure along the b-axis (Fig. 2c). As shown in Figs. $2 \mathrm{~d}$ and 2e, pbix ligand adopts two 
different conformations, namely gauche and trans, to generate a 2D polyrotaxane sheet. The values of the Co...Co separation through these bridges are 7.221, 7.943 and $11.001 \AA$. The 2D framework can be clarified as a 6-nodal net and the point symbol for net is $\left\{4.8^{3} .12^{2}\right\}_{2}\{4\}_{2}\left\{8^{4} .12^{9} .16^{2}\right\}\{8\}_{5}$ (Fig. 2f).

[Zn( $\mu$-phsuc)( $\mu$-obix $)]_{n}(3)$. X-ray diffraction result indicates that compound $\mathbf{3}$ crystallizes in the monoclinic space group $P Z_{1} / \mathrm{n}$ and features a two-dimensional (2D) network. The asymmetric unit consists of one $\mathrm{Zn}$ (II) ion, one phsuc and one obix ligand. As shown in Fig. 3a, the Zn1 ion is four-coordinated by two carboxylate oxygen atoms from two phsuc ligands and two nitrogen atoms from obix ligands, showing a distorted tetrahedral structure. The $\mathrm{Zn}-\mathrm{O}$ and $\mathrm{Zn}-\mathrm{N}$ bond lengths of previously reported $\mathrm{Zn}$ (II) complexes based on succinate ligands are similar to those of compound $\mathbf{3}$ [35]. The phsuc ligand is fully deprotonated and acts as bridging ligands with bis(monodentate) coordination modes to connect the $\mathrm{Zn}$ (II) ions to form a 1D linear structure (Fig. 3b.). Two adjacent 1D units are connected by obix ligands to give a 2D wave network (Fig. 3c). The distances between the closest Zn(II) ions are 7.746 and $13.563 \AA$. The compound shows a uninodal 4-connected sql topology with the point symbol of $\left\{4^{4} \cdot 6^{2}\right\}$ (Fig. $3 d$ ).

$\left\{[Z n(\mu \text {-phsuc)( } \mu \text {-mbix })] \cdot \mathrm{H}_{2} \mathrm{O}\right\}_{n}(4)$. Single crystal X-ray structural analysis reveals that $\mathbf{4}$ crystallizes in the monoclinic system, $P Z_{1} / \mathrm{c}$ space group. The asymmetric unit of compound $\mathbf{4}$ contains one $\mathrm{Zn}$ (II) ion, one phsuc anion, one mbix ligand, and one lattice water molecule. As shown in Fig. 4a, Zn1 is four coordinated in a tetrahedral coordination geometry, coordinated by two oxygen atoms from two different phsuc anions and two nitrogen atoms from two different mbix ligands. The $\mathrm{Zn}-\mathrm{O} / \mathrm{N}$ bond lengths are in the normal range of 1.910(17)-2.0276(17) $\AA$ as other $\mathrm{Zn}(\mathrm{II})$-containing coordination polymers. Two symmetry-related $\mathrm{Zn} 1$ ions are connected by two carboxylate groups from phsuc ligand to generate a 1D linear chain with the $\mathrm{Zn} \cdots \mathrm{Zn}$ distance of $6.358 \AA$. Each phsuc ligand acts as a bridging ligand through the two carboxylate groups as a bis(monodentate) mode (Fig. 4b). The adjacent 1D chains are further bridged by the mbix ligands to generate a 2D network (Figs. 4c and 4d). In addition, there are intrachain $\mathrm{O}-\mathrm{H} \cdots \mathrm{O}$ hydrogen-bonding interactions (Fig. 4e), which further stabilize the 1D chains of 4. Topologically, compound $\mathbf{4}$ can be simplified as a sql/Shubnikov tetragonal plane net with a point symbol of $\left\{4^{4} \cdot 6^{2}\right\}$ (Fig. 4f).

$\left\{\left[Z n(\mu \text {-phsuc) }(\mu \text {-pbix })] \cdot H_{2} O\right\}_{n}(5)\right.$. Single-crystal X-ray diffraction shows that $\mathbf{5}$ crystallizes in monoclinic system with $P Z_{1} / \mathrm{n}$ space group. The asymmetric unit of $\mathbf{5}$ contains one $\mathrm{Zn}$ (II) ion, one phsuc, and one pbix ligand and one crystal water molecule. The $\mathrm{Zn} 1$ is four-coordinated in a tetrahedral coordination environment, coordinated by two oxygen atoms from two different phsuc ligands and two nitrogen atoms from two different pbix ligands (Fig. 5a). The phsuc ligand acts as a bis(monodentate) ligand to connect with two Zn(II) ions to generate a 1D chain structure with the Zn ...Zn distance of $6.948 \AA$. The Zn 1-O distances are 1.939(4) and 1.941(4) $\AA$, and Zn1-N distances are 1.997(4) and 2.038(5) $\AA$, respectively. Adjacent the 1D chains are further linked by nitrogen atoms from pbix ligands generating a 2D wave structure (Figs. $5 \mathrm{~b}$ and $5 \mathrm{c}$ ). Topologically, the $2 \mathrm{D}$ layer can be simplified as a 4-connected sql/Shubnikov tetragonal plane net with a point symbol of $\left\{4^{4} \cdot 6^{2}\right\}$ (Fig. 5d). The 2D layers interact with each other through $\mathrm{C}-\mathrm{H} \cdots \pi$ interactions between $\mathrm{C} 7-\mathrm{H} 7, \mathrm{C} 8-\mathrm{H} 8$ and phenyl $(\mathrm{Cg} 1)$ and imidazole rings of pbix 
ligand, respectively to form a 3D supramolecular frameworks [Cg1 $=\mathrm{C} 15-\mathrm{C} 16-\mathrm{C} 17 \mathrm{~b}-\mathrm{C} 15 \mathrm{~b}-\mathrm{C} 16 \mathrm{~b}-\mathrm{C} 17$, $\mathrm{Cg} 2=\mathrm{N} 3-\mathrm{C} 18-\mathrm{C} 19-\mathrm{N} 4-\mathrm{C} 20, \mathrm{C} 7 \cdots \mathrm{Cg} 1=3.645(13)$ and $\mathrm{C} 8 \cdots \mathrm{Cg} 2=3.644(10) \AA ̊$.

$\left\{\left[\mathrm{Zn}(\mu \text {-phsuc) }(\mu \text {-pbix })] \cdot 1.5 \mathrm{H}_{2} \mathrm{O} \cdot \mathrm{CH}_{3} \mathrm{OH}\right\}_{n}(6)\right.$. It is very surprising that when solvent mixture $\left(\mathrm{H}_{2} \mathrm{O}(30 \mathrm{~mL})\right.$ and $\left.\mathrm{C}_{2} \mathrm{H}_{5} \mathrm{OH}(3.5 \mathrm{~mL})\right)$ for the synthesis of 5 is replaced with solvent mixture $\left(\mathrm{H}_{2} \mathrm{O}(5 \mathrm{~mL}), \mathrm{DMF}(5 \mathrm{~mL})\right.$ and $\left.\mathrm{CH}_{3} \mathrm{OH}(5 \mathrm{~mL})\right)$, two-fold interpenetrated network of 6 is observed. Compound 6 shows a 2D network and it crystallizes in monoclinic system $\mathrm{C2} / \mathrm{c}$. The asymmetric unit consists of one $\mathrm{Zn}(\mathrm{II})$ ion, one phsuc, one pbix, one methanol and one and a half water molecules (Fig. 6a). The Zn1 atom is four-coordinated and forms a disordered tetrahedral geometry, which is completed by two carboxylate oxygen atoms from two distinct phsuc moieties and two nitrogen donors from two pbix ligands. The lengths of the $\mathrm{Zn}-\mathrm{O}$ (1.951(6)-1.959(6) $\AA$ ) and Zn-N (2.002(7) and 2.000(7) $\AA$ ) bonds are comparable to those observed in the related literature [35]. The adjacent $\mathrm{Zn}$ (II) ions are connected by bridging carboxylate groups of phsuc ligands into a 1D double chain with the Zn ‥Zn distance of $9.291 \AA$ A. Further, every Zn(II) ion are coordinated with two pbix ligands showing gauche form, and a two-fold interpenetrating 2D structure with bimetallic 26-member rings is observed (Fig. 6b.) Two adjacent 2D networks interpenetrate each other to form a 2D $+2 D \rightarrow 2 D$ interpenetration network (Fig. 6c). The final framework of 6 can be considered as a uninodal 3-connected hcb Shubnikov hexagonal plane net with the point symbol of $\left\{6^{3}\right\}$ (Fig. 6d).

[Cd( $\mu$-phsuc) $(\mu$-obix $)]_{n}(7)$. X-ray diffraction shows that 7 crystallizes in monoclinic system with $P{ }_{1} / \mathrm{n}$ space group. The asymmetric unit contains one $\mathrm{Cd}(\mathrm{II})$ ion, one phsuc and obix ligands. As shown in Fig. $7 \mathrm{a}$, the $\mathrm{Cd} 1$ ion is coordinated by four oxygen atoms from two different phsuc ligands and two nitrogen atoms from two different obix ligands. The $\mathrm{Cd}-\mathrm{O} / \mathrm{N}$ bond lengths are in the range of 2.245(4) to 2.470(4) $\AA$. The phsuc ligands in 7 adopt a bis(bidentate) bridging coordination mode linking the neighbouring $\mathrm{Cd}(\mathrm{II})$ ions to generate 1D linear chain along the a-axis with $\mathrm{Cd}(\mathrm{II}) \cdots \mathrm{Cd}(\mathrm{II})$ distances of $7.570 \AA$ (Fig. $7 \mathrm{~b}$ ). The adjacent 1D chains are linked to form a 2D wave-like structure along the $c$-axis by obix ligands (Fig. 7c). There are $\pi \cdots \pi$ interactions between the imidazole rings $\left(\mathrm{Cg} 1=\mathrm{N} 1-\mathrm{C} 11-\mathrm{C} 12-\mathrm{N} 2-\mathrm{C} 13, \mathrm{Cg} 1 \cdots \mathrm{Cg} 1^{\mathrm{i}}=\right.$ $3.544(3) \AA$, (i) 1-x, 1-y, 1-z). Furthermore, there are also weak $\mathrm{C}-\mathrm{H} \cdots \pi$ interactions between the $\mathrm{C} 13-\mathrm{H} 13$ and phenyl ring $(\mathrm{Cg} 2)$ of phsuc ligand (Cg2 = C5-C6-C7-C8-C9-C10, C13 ‥Cg2 = 3.516(5) $\AA$ ). All of these intermolecular interactions give a three-dimensional supramolecuşar network (Fig. 7d). Topologically, compound $\mathbf{7}$ can be simplified as a 4-connected sql/Shubnikov tetragonal plane net with a point symbol of $\left\{4^{4} \cdot 6^{2}\right\}$ (Fig. 7e).

[Cd( $\mu_{3}$-phsuc)( $\mu$-pbix $\left.)_{0.5}\right]_{n}(8)$. Compound 8 crystallizes in a triclinic with space group $P 21 / \mathrm{n}$. There is one $\mathrm{Cd}(\mathrm{II})$ ion, one phsuc ligand, a half pbix ligands in an asymmetric unit of $\mathbf{8}$. As shown in Fig. 8 a, the $\mathrm{Cd} 1$ is six-coordinated by five oxygen atoms from two different phsuc ligands, and one nitrogen atom from pbix ligand. The lengths of the $\mathrm{Cd}-\mathrm{O}(2.278$ (4) - 2.385 (4) $\AA$ ) and $\mathrm{Cd}-\mathrm{N}(2.209$ (3) $\AA$ ) bonds are comparable to those observed in the related literature [36-39]. There are two coordination modes for the carboxylate groups of the phsuc ligand, with one in a $\mu-\eta^{1}: \eta^{1}$ chelating mode and the other in a $\mu_{3}-\eta^{1}: \eta^{2}$ tridentate bridging mode (Fig. 8b). The closest three $\mathrm{Cd}(\mathrm{II})$ ions are bridged together through the carboxylate groups 
of the phsuc ligands to generate a 14-membered rings based on the $\left[\mathrm{Cd}_{2}\left(\mathrm{CO}_{2}\right)_{4}\right]$ unit with a $\mathrm{Cd} 1 \cdots \mathrm{Cd} 1$ distance of $6.139 \AA$. The $\left[\mathrm{Cd}_{2}\left(\mathrm{CO}_{2}\right)_{4}\right]$ clusters are further connected by pbix ligands to form a $2 \mathrm{D}$ network (Fig. $8 \mathrm{C}$ ). The neighboring 2D layers are further assembled by weak $\pi \cdots \pi$ stacking interactions, with centroid-centroid (Cg1 $=$ C5-C6-C7-C8-C9-C10) distance of 4.095(3) $\AA$, and C-H $\cdots \pi(C 16 \cdots \mathrm{Cg} 1=$ 3.598(6) $\AA$ and $\mathrm{C} 16-\mathrm{H} 16 \cdots \mathrm{Cg} 1=141^{\circ}$ ) interactions into the 3D supramolecular framework (Fig. 8d).

Topologically, if the $\mathrm{Cd}$ (II) center is regarded as a four-connected node and the phsuc ligand is considered as linker, the structure of $\mathbf{8}$ can be described as a 4-connected layer with sql/Shubnikov tetragonal plane topology with the point symbol of $\left\{4^{4} \cdot 6^{2}\right\}$ (Fig. 8e).

\subsection{Powder X-ray diffraction and thermal properties}

The phase purities of the compounds were determined with powder X-ray diffraction (PXRD) measurements (Figs. S9-S15.). All the major peaks of the recorded PXRD patterns are agreed with those of the simulated patterns, demonstrating the phase purities of the compounds.

Thermal analysis curves of the compounds were recorded in the temperature range $30-1000{ }^{\circ} \mathrm{C}$ under a dry air atmosphere to determine the thermal behaviors of the compounds (Fig. S16-S23). For compounds 2 and 4-6, the first weight losses are related to eliminations of crystal water molecules (Exp.: $3.8 \%$ calc.: $4.1 \%$ for 2 ; exp.: $4.1 \%$ calc.: $3.5 \%$ for 4 ; exp.: $3.0 \%$ calc.: $3.5 \%$ for 5 ; exp.: $10.54 \%$ calc.: $10.63 \%$ for 6 ). After the steps, compounds 2 and $4-6$ displayed stability up to $200-280^{\circ} \mathrm{C}$ and anhydrous compounds $1,3,7$ and 8 showed stability up to $300^{\circ} \mathrm{C}$. When further heating, all compounds are exothermally decomposed and the final decomposition products can be $\mathrm{Co}_{3} \mathrm{O}_{4}$ which turns to $\mathrm{CoO}$ over $905^{\circ} \mathrm{C}$ for 1 and 2 , and $\mathrm{ZnO}$ for 3-6 and CdO for $\mathbf{7}$ and 8. (CoO, exp.:17.8\%, calc.: $15.31 \%$ for $\mathbf{1}$; exp.: $9.27 \%$, calc.: $8.36 \%$ for $\mathbf{2}$; ZnO, exp.: $16.11 \%$, calc.: $16.42 \%$ for 3 ; exp.: $13.07 \%$, calc.: $15.76 \%$ for 4 ; exp.: $17.22 \%$, calc.: $15.77 \%$ for 5 ; exp.:8.4\%, calc.: $14.6 \%$ for 6 ; CdO, exp.: $21.83 \%$, calc.: $23.65 \%$ for 7 ; exp.: $27.8 \%$, calc.: $30.3 \%$ for 8 )

\subsection{Photoluminescence properties}

Solid-state photoluminescence spectra of compounds $3-\mathbf{8}$ with the $\mathrm{d}^{10}$ metal center were recorded under the same conditions at room temperature. As seen in Fig. 9, phsucH $\mathrm{H}_{2}$ displayed very weak emission at 360 and $425 \mathrm{~nm}$ upon excitation at $300 \mathrm{~nm}$. In our previous study, isomeric bis(imidazole) linkers showed emissions in the range of $409-428 \mathrm{~nm}$ with the excitation at $300 \mathrm{~nm}$. These emissions were assigned to $\pi^{*} \rightarrow \pi$ or $\pi^{*} \rightarrow n$ transitions of the ligands [40]. Compounds 3-8 showed emission maxima at 440, 384, $368,422,440$ and $382 \mathrm{~nm}$, respectively upon excitation at $300 \mathrm{~nm}$. The shifted emissions of the compounds, when compared to free ligands, could be assigned to formation of coordination bonds.

\section{Conclusion}

Eight coordination polymers were prepared with phsucH $_{2}$ and isomeric semi-flexible bis(imidazole) linkers in the presence of diverse $\mathrm{M}(\mathrm{II})$ ions and characterized by several techniques. X-ray results showed that the phsuc ${ }^{2-}$ connected the metal ions to form one dimensional chains which were extended to $2 \mathrm{D}$ structures by coordination of bis(imidazole) linkers. Moreover, all compounds were extended to 3D 
supramolecular structure via $\pi \cdots \pi$ stacking and weak $\mathrm{C}-\mathrm{H} \cdots \pi$ interactions. The phsuc ${ }^{2-}$ ligand displayed diverse coordination modes in the compounds and pbix ligand showed trans-and gauche-conformations due to its flexible nature. The emissions of the compounds were assigned to the intra-ligand transition of bis(imidazole) linkers because it was difficult to oxidize or reduce the $\mathrm{d}^{10}$ metal ions

\section{Declarations}

\section{Acknowledgments}

This work has been supported by Eskisehir Osmangazi University Scientific Research Projects Coordination Unit under grant number 201919D04.

\section{Supporting Information}

The Cambridge Crystallographic Data Centre with CCDC No. 2142948-2142955 for 1-8 have deposited the crystallographic data for the structural analysis. Copies of this information may be obtained free of charge from the Director, CCDC, 12 Union Road, Cambridge CB2 1EZ, UK (fax: +44-1223-336033; e-mail: deposit@ccdc.cam.ac.uk or www: http://www.ccdc.cam.ac.uk).

\section{References}

1. X. Feng, Y. Shang, H. Zhang, R. Li, W. Wang, D. Zhang, L. Wang, Z. Li, Enhanced luminescence and tunable magnetic properties of lanthanide coordination polymers based on fluorine substitution and phenanthroline ligand. RSC Adv. 9, 16328-16338 (2019)

2. S. Mukherjee, D. Sensharma, K.-J. Chen, M.J. Zaworotko, Crystal engineering of porous coordination networks to enable separation of C2 hydrocarbons. Chem. Commun. 56, 10419-10441 (2020)

3. Y. Güçlü, H. Erer, H. Demiral, C. Altintas, S. Keskin, N. Tumanov, B.L. Su, F. Semerci, Oxalamidefunctionalized metal organic frameworks for $\mathrm{CO}_{2}$ adsorption. ACS Appl. Mater. Interfaces 13, 33188-33198 (2021)

4. A. Çiftlik, T.c.e Günay, O. Semerci, F. Şahin, Semerci, Two-Dimensional Metal-Organic Framework Nanostructures Based on 4, 4'-Sulfonyldibenzoate for Photocatalytic Degradation of Organic Dyes. Cryst. Growth Des. 21, 6 3364-3374 (2021)

5. A. Sun, Y. Yang, Y. Liu, L. Ding, P. Duan, W. Yang, Q. Pan, A Zinc Coordination Polymer Sensor for Selective and Sensitive Detection of Doxycycline Based on Fluorescence Enhancement. Cryst. Growth Des. 21, 4971-4978 (2021)

6. M. Arici, T.A. Arici, H. Demiral, M. Taş, O.Z. Yeşilel, A porous Zn (ii)-coordination polymer based on a tetracarboxylic acid exhibiting selective $\mathrm{CO}_{2}$ adsorption and iodine uptake. Dalton Trans. 49, 1082410831 (2020)

7. T.A. Arici, O.Z. Yeşilel, M. Arici, A water-stable 2D+2D $\rightarrow$ 3D polycatenated coordination polymer for selective adsorption of methylene blue and detection of $\mathrm{Fe}^{3+}$ ion from aqueous solution. J. Taiwan. 
Inst. Chem. Eng. 114, 300-310 (2020)

8. G.G. Sezer, O.Z. Yeşilel, M. Arıcı, H. Erer, Temperature-controlled formation of two Zn (II)-coordination polymers based on flexible o-phenylenediacetic acid and rigid 1,4-bis (imidazol-1-yl) benzene. Polyhedron 102, 514-520 (2015)

9. Y.F. Hou, B. Liu, K.F. Yue, C.S. Zhou, Y.M. Wang, N. Yan, Y.Y. Wang, Five solvent-induced cadmium coordination polymers (CPs) based on the same mixed ligands. CrystEngComm 16, 9560-9567 (2014)

10. C. Gong, H. Guo, X. Zeng, H. Xu, Q. Zeng, J. Zhang, J. Xie, Flexible and rigid dicarboxylic acids enable the assembly of achiral and chiral 3D Co(II) metal-organic frameworks. Dalton Trans. 47, 69176923 (2018)

11. W. Qiu, J.A. Perman, $Ł$ Wojtas, M. Eddaoudi, M.J. Zaworotko, Structural diversity through ligand flexibility: two novel metal-organic nets via ligand-to-ligand cross-linking of "paddlewheels". Chem. Commun. 46, 8734-8736 (2010)

12. A. Halder, B. Bhattacharya, F. Haque, D. Ghoshal, Structural diversity in six mixed ligand Zn (II) metal-organic frameworks constructed by rigid and flexible dicarboxylates and different N, N' donor ligands. Cryst. Growth Des. 17, 6613-6624 (2017)

13. U. Patel, B. Parmar, P. Patel, A. Dadhania, E. Suresh, The synthesis and characterization of Zn (II)/Cd (II) based MOFs by a mixed ligand strategy: a Zn(II) MOF as a dual functional material for reversible dye adsorption and as a heterogeneous catalyst for the Biginelli reaction. Mater. Chem. Front. 5, 304-314 (2021)

14. M. Du, C.P. Li, C.S. Liu, S.M. Fang, Design and construction of coordination polymers with mixedligand synthetic strategy. Coord. Chem. Rev. 257, 1282-1305 (2013)

15. F.J. Teixeira, L.S. Flores, L.B. Escobar, T.C. dos Santos, M.I. Yoshida, M.S. Reis, S. Hill, C.M. Ronconi, C.C. Corrêa, A 3D interpenetrated Co(II)-glutarate coordination polymer: Synthesis, crystal structure, magnetic and adsorption properties. Inorg. Chim. Acta 511, 119791 (2020)

16. B. Dutta, A. Hazra, A. Dey, C. Sinha, P.P. Ray, P. Banerjee, M.H. Mir, Construction of a succinate-bridged $\mathrm{Cd}(\mathrm{II})$-based two-dimensional coordination polymer for efficient optoelectronic device fabrication and explosive sensing application. Cryst. Growth Des. 20, 765-776 (2020)

17. X. Cheng, J. Hu, J. Zhang, Structure of imidazolidyl Co(II) coordination polymer and catalytic properties of thermal conversion products. Inorg. Chim. Acta 506, 119540 (2020)

18. D.Y. Li, H. Xie, X.Q. Yao, H.C. Ma, Z.Q. Lei, J.C. Liu, A luminescent coordination polymer based on a $\pi-$ conjugated ligand: Syntheses, structure and luminescent property. J. Mol. Struc 1134, 171-173 (2017)

19. P.K. Yaman, Syntheses and characterizations of copper(II)-supramolecular coordination compounds with 2,2-dimethylglutarate and diamine derivatives. J. Mol. Struc 1225, 129097 (2021)

20. P.K. Yaman, H. Erer, M. Arıcı, I. Erucar, O.Z. Yeşilel, Hydrothermal synthesis and characterization of two dimensional coordination polymers with 2,2'-dimethylglutarate and 1, 2-bis(imidazol-1-ylmethyl) benzene. Inorg. Chim. Acta 488, 229-237 (2019) 
21. P.K. Yaman, M. Arıcı, H. Erer, O.Z. Yeşilel, The Effect of Metal Salts on The Structures of 2, 2Dimethylglutarate Complexes with a Flexible 1, 4-bis(imidazol-1-ylmethyl)-2,3,5,6tetramethylbenzene. J. Mol. Struc 1229, 129499 (2021)

22. P.K. Yaman, H. Erer, O.Z. Yeşilel, Three dimensional manganese(II) coordination polymers constructed from 2, 2-dimethylglutarate and bis(pyridyl) type ligands. Polyhedron 171, 317-322 (2019)

23. F.A. Biçer, Hydrothermal Synthesis and Crystal Structure of Zn(II) Coordination Polymer with the Rigid 4,4'-azobispyridine. J. Turkish Chem. Soc. 7, 43-48 (2020)

24. L.P. Zhang, L.L. LV, W.J. Li, H.M. Yang, Y.Z. Cheng, Synthesis and crystal structure of a new 1D Pb(II) coordination polymer constructed from phenylsuccinic acid. Main Group. Met. Chem. 40, 81-85 (2017)

25. J. Zhou, C.Y. Sun, L.P. Jin, Solvothermal syntheses and crystal structures of new $\mathrm{Cu}(\mathrm{II})$ complexes with phenylsuccinic acid. Polyhedron 26, 4025-4032 (2007)

26. A.R. Li, Q.Q. Guo, L. Li, H.W. Hou, Y.T. Fan, Synthesis, characterization and properties of four dimeric Znll-BMP coordination polymers modulated by a series of aromatic polycarboxylate acid. Polyhedron 71, 17-23 (2014)

27. S. Hu, P. Zhang, F.Y. Yu, D.R. Lin, M.X. Chen, Constructions of two photoluminescent 3D coordination polymers comprising of hydroxide-bridged cadmium chain and polynuclear cadmium macrocycle using phenylsuccinic acid. J. Mol. Struc 1051, 72-77 (2013)

28. D. Wu, W. Meng, L. Zhang, L. Liu, H. Hou, Y. Fan, Construction of four coordination polymers with helical character based on a flexible bis(triazole) derivative and dicarboxylate coligands. Inorg. Chim. Acta 405, 318-325 (2013)

29. G.G. Sezer, O.Z. Yeşilel, O. Şahin, A.D. Burrows, Zinc(II) and cadmium (II) coordination polymers containing phenylenediacetate and bis(imidazol-1-ylmethyl)benzene linkers: The effect of ligand isomers on the solid state structures. J. Solid State Chem. 252, 8-21 (2017)

30. O.V. Dolomanov, L.J. Bourhis, R.J. Gildea, J.A. Howard, H. Puschmann, OLEX2: a complete structure solution, refinement and analysis program. J. Appl. Crystallogr. 42, 339-341 (2009)

31. G.M. Sheldrick, SHELXT-Integrated space-group and crystal-structure determination. Acta Crystallogr. A: Found. Adv. 71, 3-8 (2015)

32. G.M. Sheldrick, Crystal structure refinement with SHELXL. Acta Crystallogr. C Struct. Chem. 71, 3-8 (2015)

33. C.F. Macrae, P.R. Edgington, P. McCabe, E. Pidcock, G.P. Shields, R. Taylor, M. Towler, J. Streek, Mercury: visualization and analysis of crystal structures. J. Appl. Crystallogr. 39, 453-457 (2006)

34. V.A. Blatov, A.P. Shevchenko, D.M. Proserpio, Applied topological analysis of crystal structures with the program package ToposPro. Cryst. Growth Des. 14, 3576-3586 (2014)

35. H.Q. Hao, J.X. Li, L. Li, M.X. Peng, Zn(II)/Ni(II) coordination polymers with 2-phenylsuccinate and 1,3bis(4-pyridyl)propane. J. Coord. Chem. 65, 2561-2568 (2012) 
36. R. Vaidhyanathan, S. Natarajan, C.N.R. Rao, Open-framework cadmium succinates with interpenetrating frameworks formed by tetrahedral $\left[\mathrm{ClCd}_{4} \mathrm{O}_{24}\right]$ and $\left[\mathrm{BrCd}_{4} \mathrm{O}_{24}\right]$ clusters. Cryst. Growth Des. 3, 47-51 (2003)

37. R. Vaidhyanathan, S. Natarajan, C.N.R. Rao, Open-framework cadmium succinates of different dimensionalities. Inorg. Chem. 41, 5226-5234 (2002)

38. C.L. White, M.D.T. Salgado, J.E. Mizzi, R.L. LaDuca, Divergent layer topologies in divalent metal aliphatic dicarboxylate coordination polymers containing 3-pyridylmethylnicotinamide. J. Mol. Struct. 1101, 147-154 (2015)

39. B. Bhattacharya, R. Dey, D. Ghoshal, Synthesis, crystal structure and photo luminescent property of a 3D metal-organic hybrid of Cd(II) constructed by two different bridging carboxylate. J. Chem. Sci. $125,661-666$ (2013)

40. M. Arici, Y.C. Dikilitas, H. Erer, O.Z. Yesilel, Cobalt(II) and zinc(II)-coordination polymers constructed from ether-linked tetracarboxylic acid and isomeric bis(imidazole) linkers: luminescence-based Fe(III) detection in aqueous media. Crystengcomm 22, 5776-5785 (2020)

\section{Scheme}

Schemes 1 is available in the Supplementary Files section.

\section{Figures}




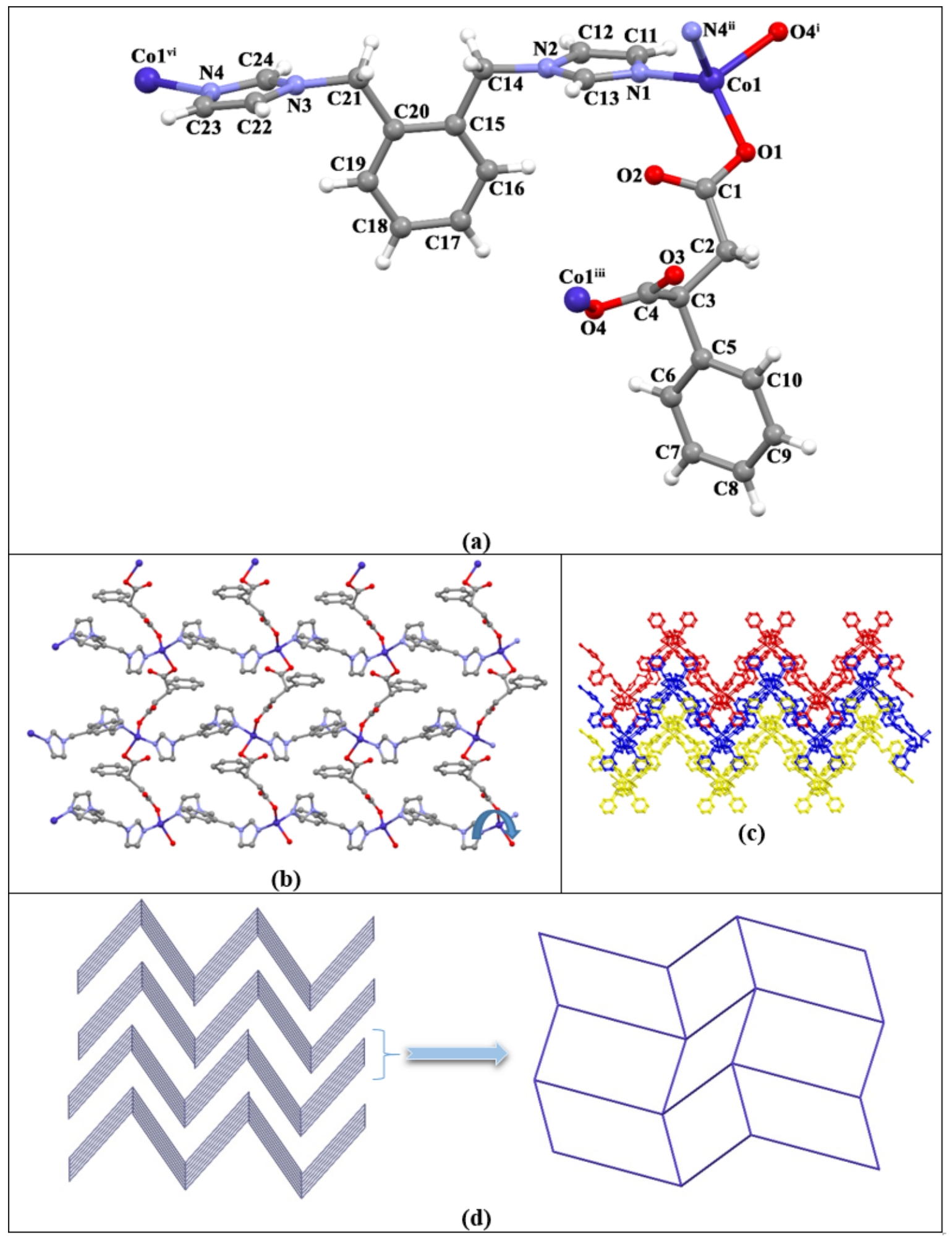

Figure 1

(a) View of the molecular structure of 1 with the atom numbering scheme (b) View of the twodimensional network of 1. (Hydrogen atoms have been omitted for clarity), (c) View of the 3D supramolecular structure of 1 (d) The schematic view of sql topology of 1 ((i) $x+1 / 2, y,-z+1 / 2 ;$ (ii) $x,-y+1 / 2, z-1 / 2$; (iii) $x-1 / 2, y,-z+\frac{1}{2} ;$; (iv) $x,-y+1 / 2, z+1 / 2$ ). 


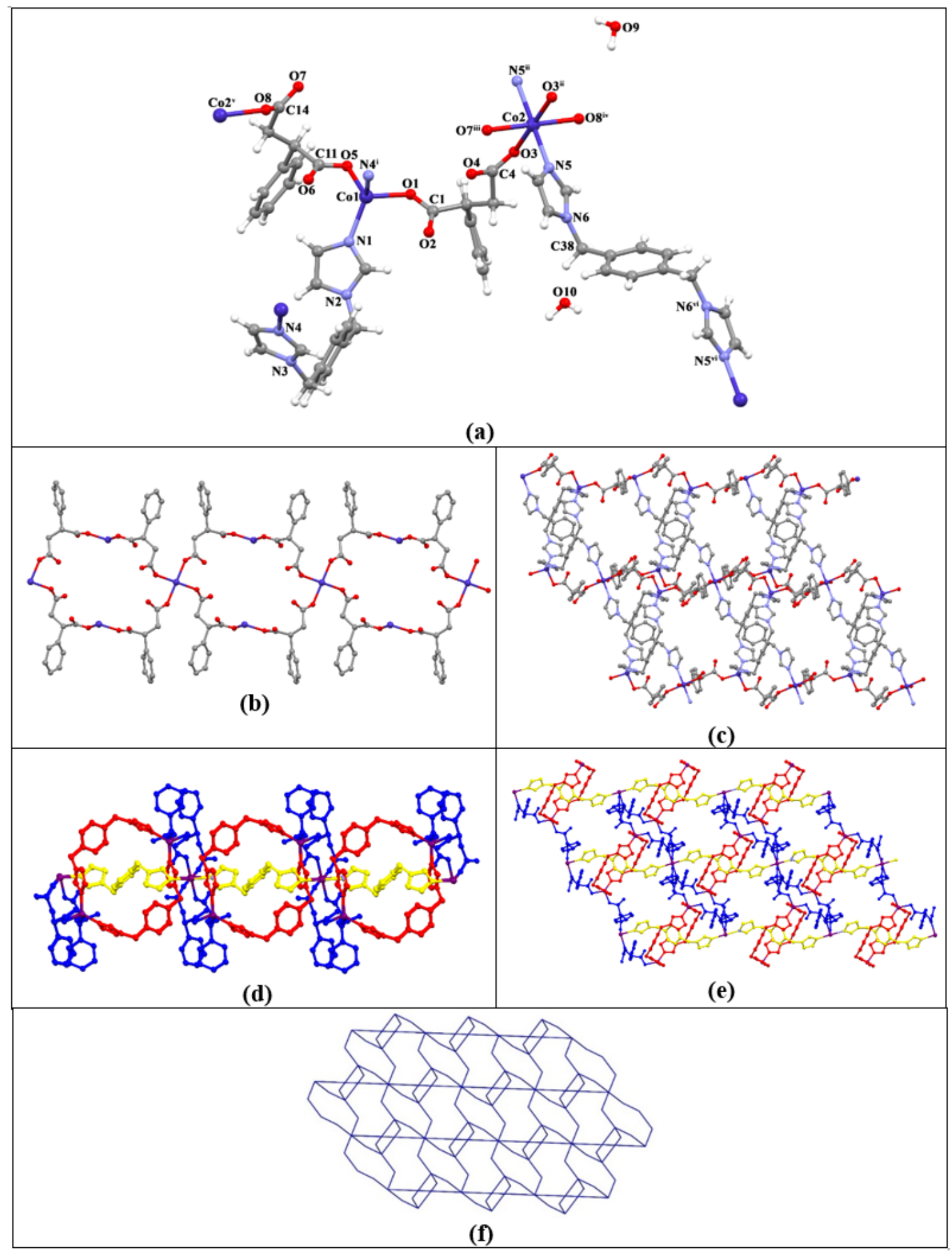

Figure 2

(a) View of the molecular structure of $\mathbf{2}$ with the atom numbering scheme (b) View of the 1D structure of 2 (Hydrogen atoms have been omitted for clarity), (ce-) View of the 2D supramolecular structure of 2 (f) The schematic view of topology of 2 ((i) $-x,-y,-z$; (ii) $-x+1,-y+1$, -z; (iii) $-x+1,-y,-z$; (iv) $x, y+1, z$; (v) $x, y-1, z$; (vi) $-x,-y+2,-z)$ 


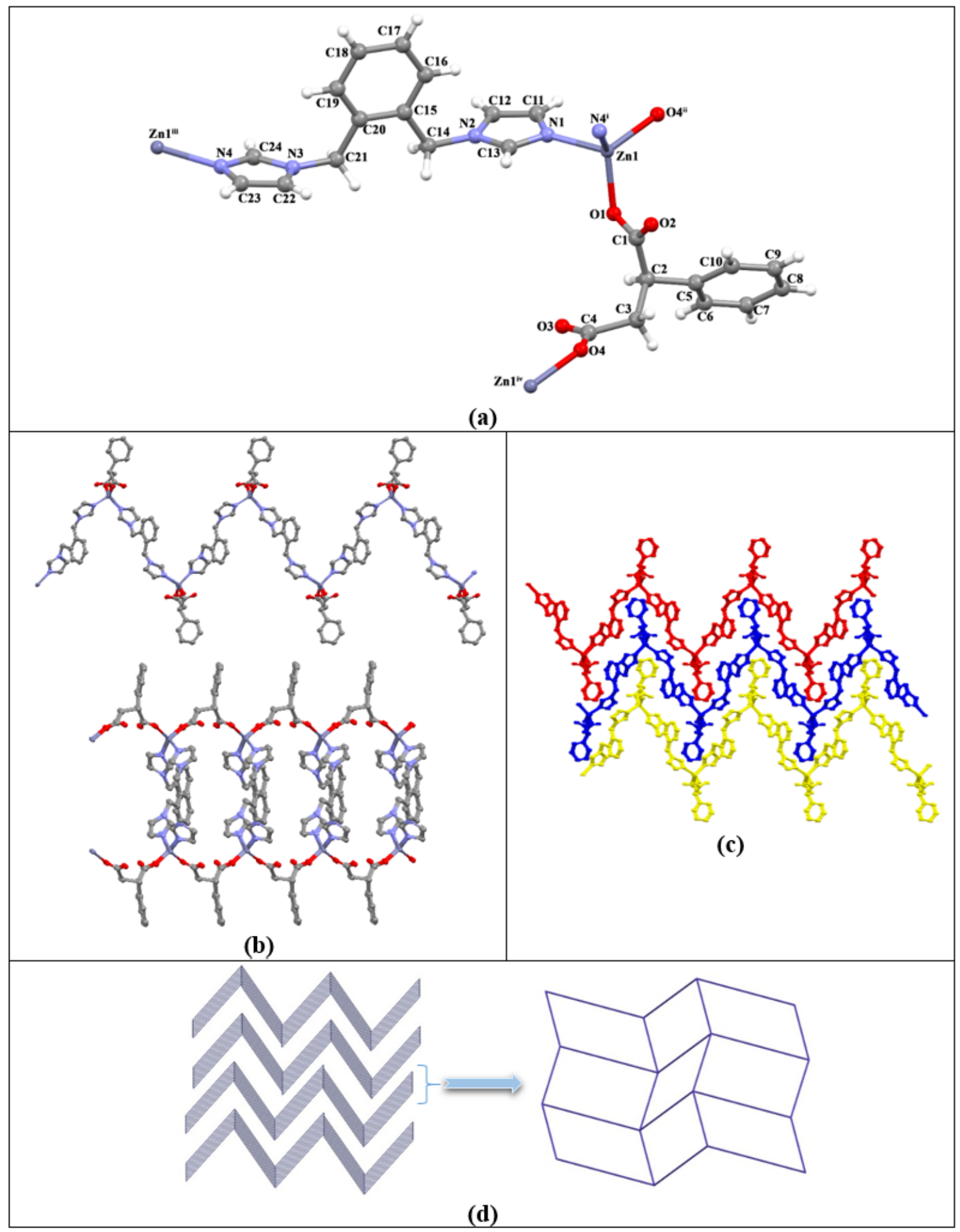

\section{Figure 3}

(a) View of the molecular structure of $\mathbf{3}$ with the atom numbering scheme (b) View of the twodimensional network of $\mathbf{3}$ (Hydrogen atoms have been omitted for clarity), (c) View of the 3D supramolecular structure of $\mathbf{3}$ (d) The schematic view of sql topology of $\mathbf{3}$ ((i) $x-1 / 2,-y+1 / 2, z+1 / 2 ;$;ii) $x-1, y$, $z$, (iii) $x+\frac{1}{2},-y+\frac{1}{2}, z^{-1 / 2}$; (iv) $x+1, y, z$.) 


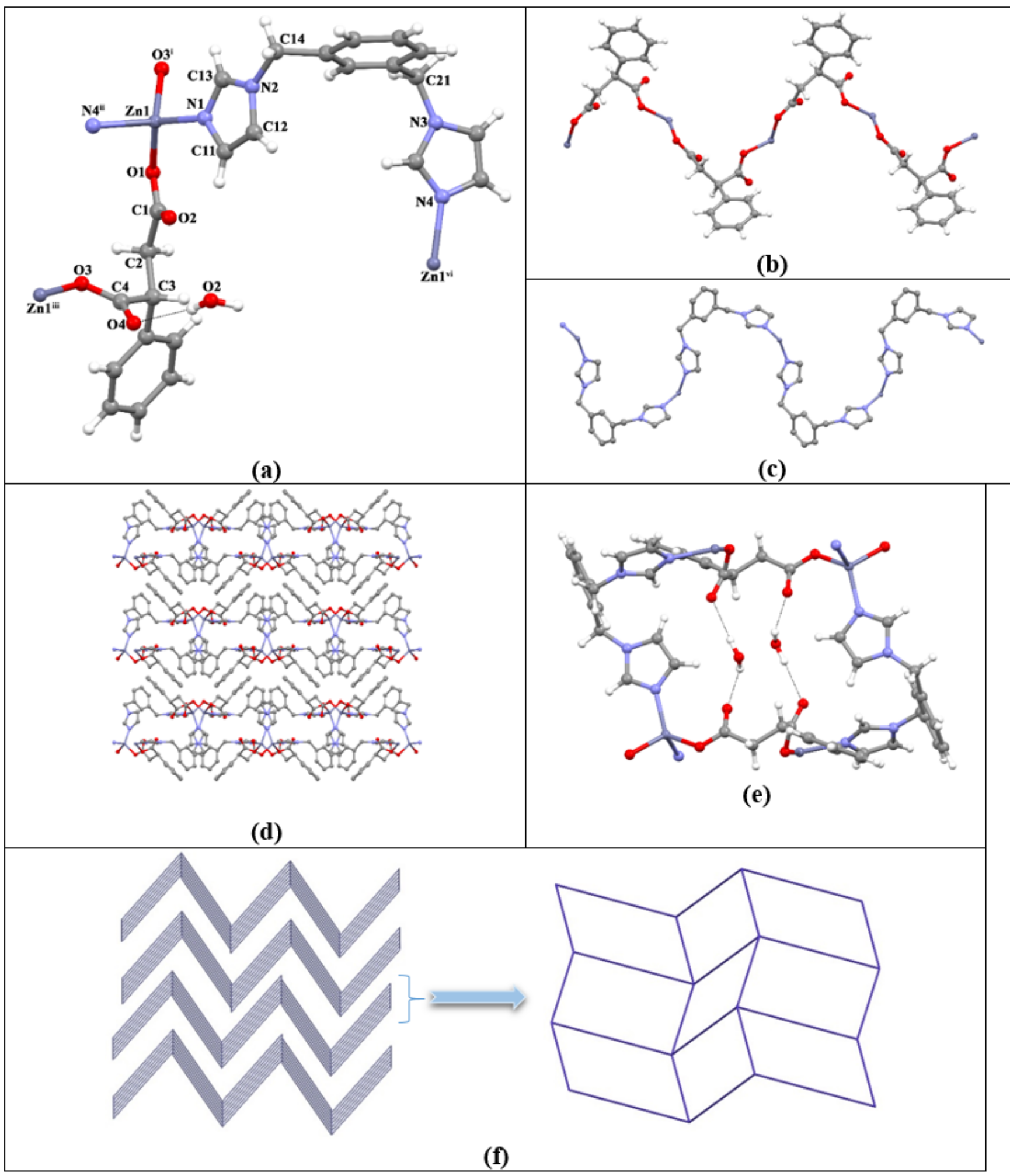

\section{Figure 4}

(a) View of the molecular structure of $\mathbf{4}$ with the atom numbering scheme (b) View of the onedimensional chain constructed by phsuc ligands (Hydrogen atoms have been omitted for clarity) (c) View of the one-dimensional chain constructed by pbix ligands (d) View of the 3D supramolecular structure of 4 (e) A view of the hydrogen bonding interaction (f) The schematic view of sql topology of $\mathbf{4}$ ((i) $x,-y+1 / 2$, $z^{-1 / 2}$; (ii) $-x+1, y-1 / 2,-z+1 / 2$; (iii) $x,-y+1 / 2, z+1 / 2$; (iv) $-x+1, y+1 / 2,-z+1 / 2$.) 


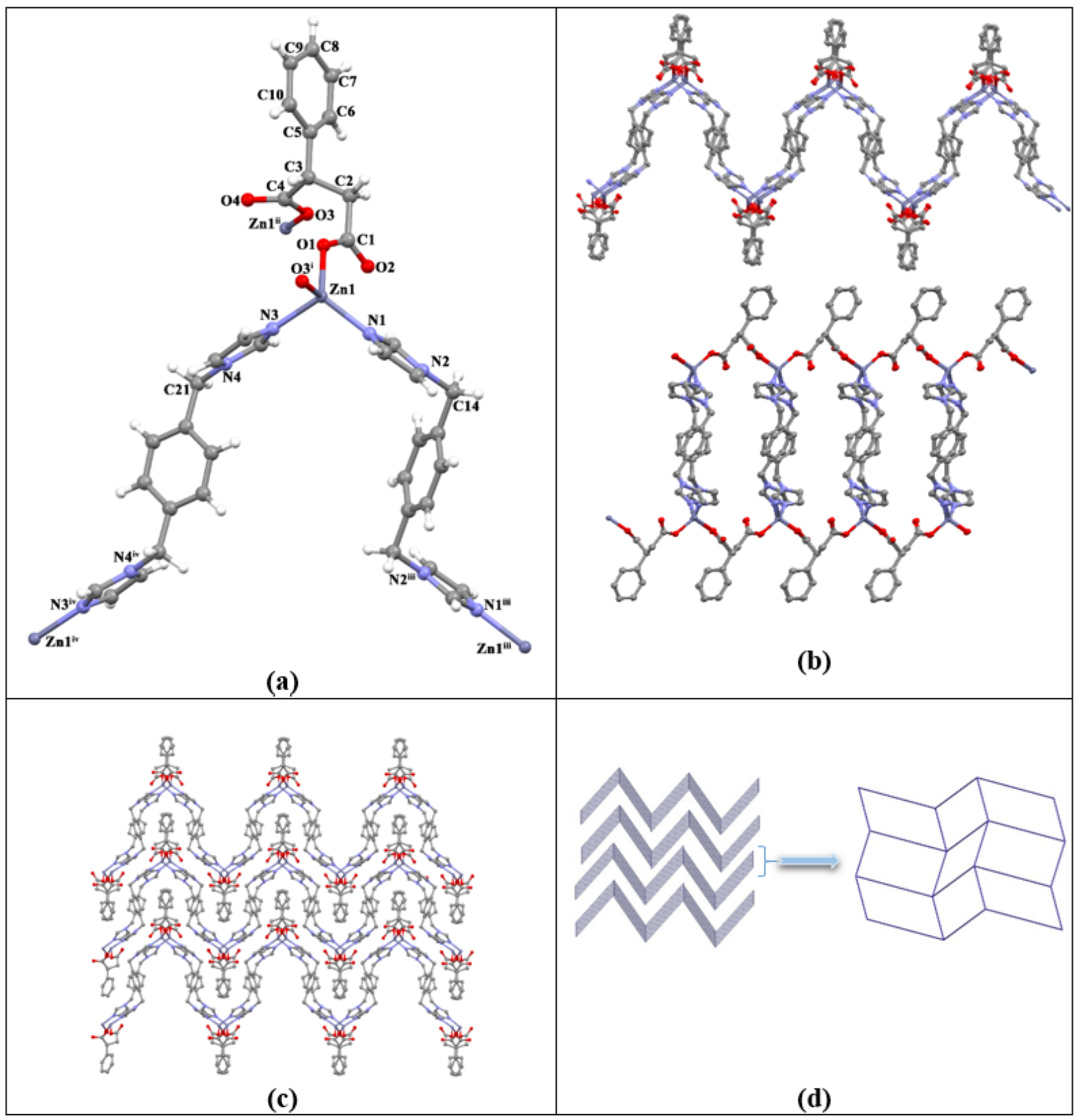

Figure 5

(a) View of the molecular structure of $\mathbf{5}$ with the atom numbering scheme (b) View of the twodimensional network of $\mathbf{5}$ (Hydrogen atoms have been omitted for clarity) (c) View of the 3D supramolecular structure of $\mathbf{5}$ (d) The schematic view of sql topology of $\mathbf{5}$ ((i) $x-1 / 2,-y+1 / 2, z-1 / 2 ;$;ii) $x+1 / 2$, $-y+1 / 2, z+1 / 2 ;$ (iii) $-x+1,-y,-z$, (iv) $-x+1,-y+1,-z$ ) 


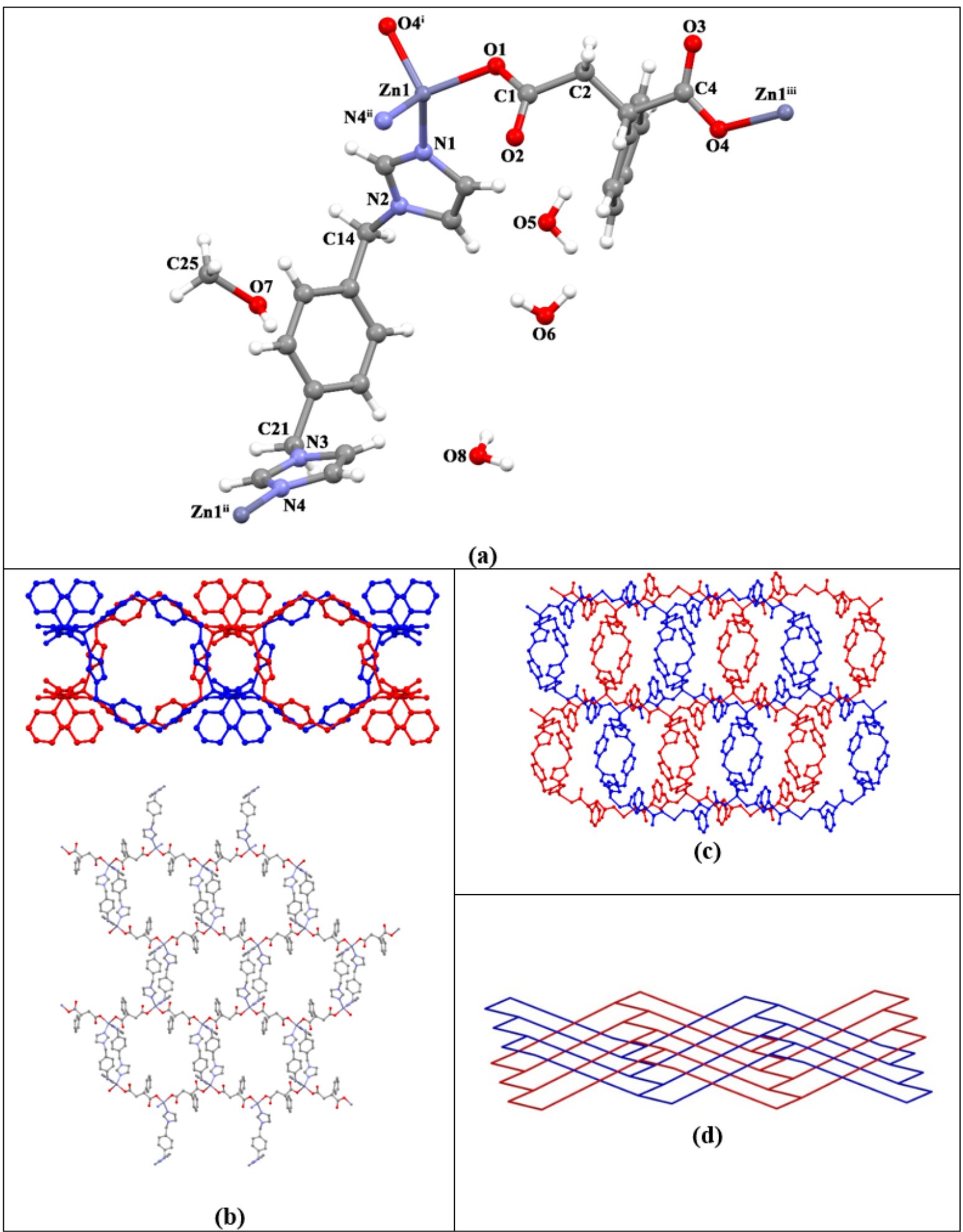

Figure 6

(a) View of the molecular structure of 6 with the atom numbering scheme (b) View of the twodimensional network of 6 (Hydrogen atoms have been omitted for clarity), (c) View of the 2D+2D ${ }^{\circledR} 2 D$ interpenetration structure of 6 (d) The schematic view of hcb topology of 6 ((i) $x,-y+2, z+\frac{1}{2}$; (ii) $-x+1$, $-y+1,-z+1$; (iii) $x,-y+2, z-1 / 2)$ 


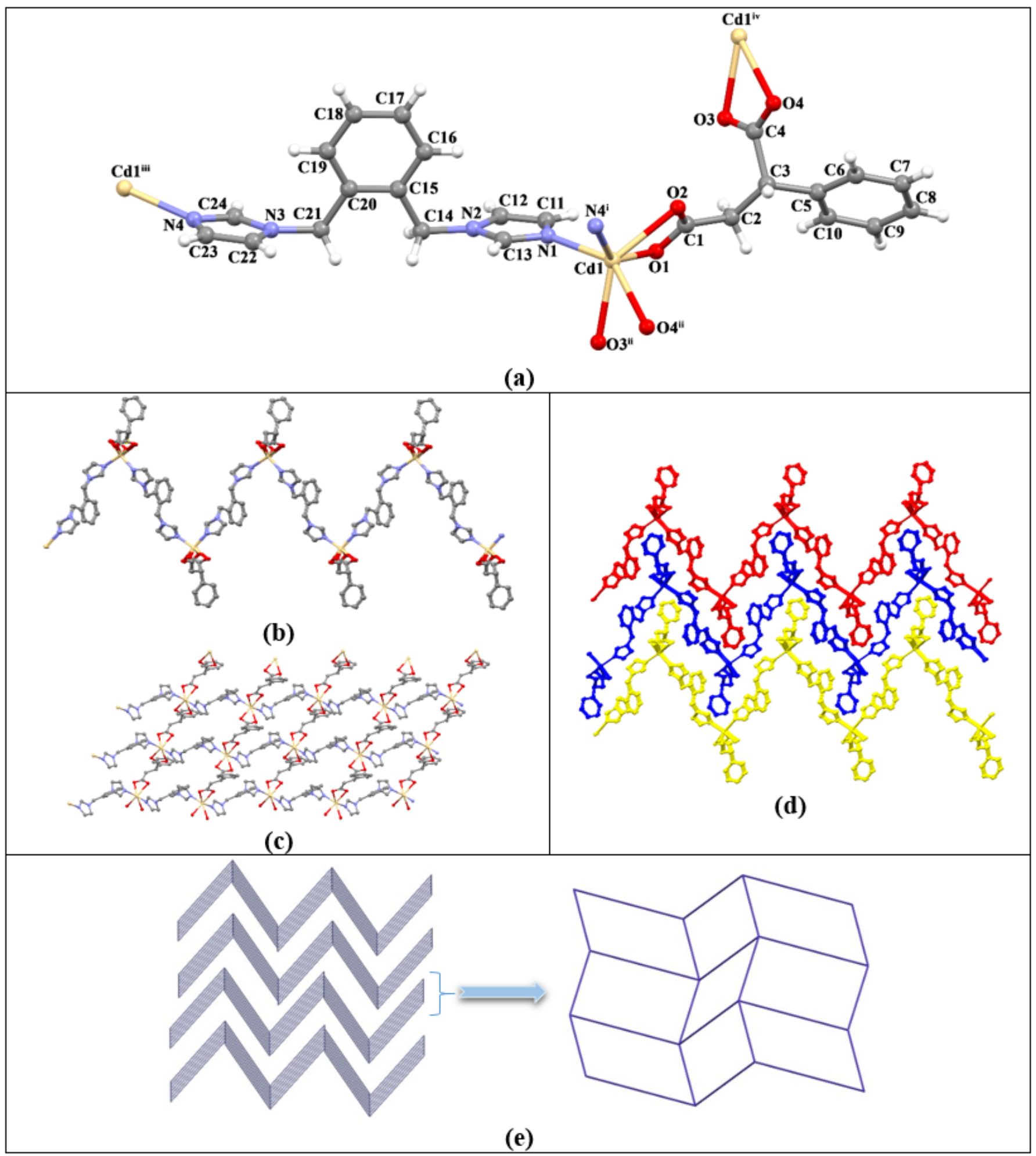

Figure 7

(a) View of the molecular structure of 7 with the atom numbering scheme (b) View of the onedimensional structure of 7 (c) View of the two-dimensional structure of 7 (Hydrogen atoms have been omitted for clarity) (c) View of the 3D supramolecular structure of 7 (d) The schematic view of sql topology of 7 ((i) $x+\frac{1}{2},-y+\frac{1}{2}, z^{-1 / 2}$; (ii) $x-1, y, z$, (iii) $x-1 / 2,-y+\frac{1}{2}, z+1 / 2$; (iv) $x+1, y, z$ ). 


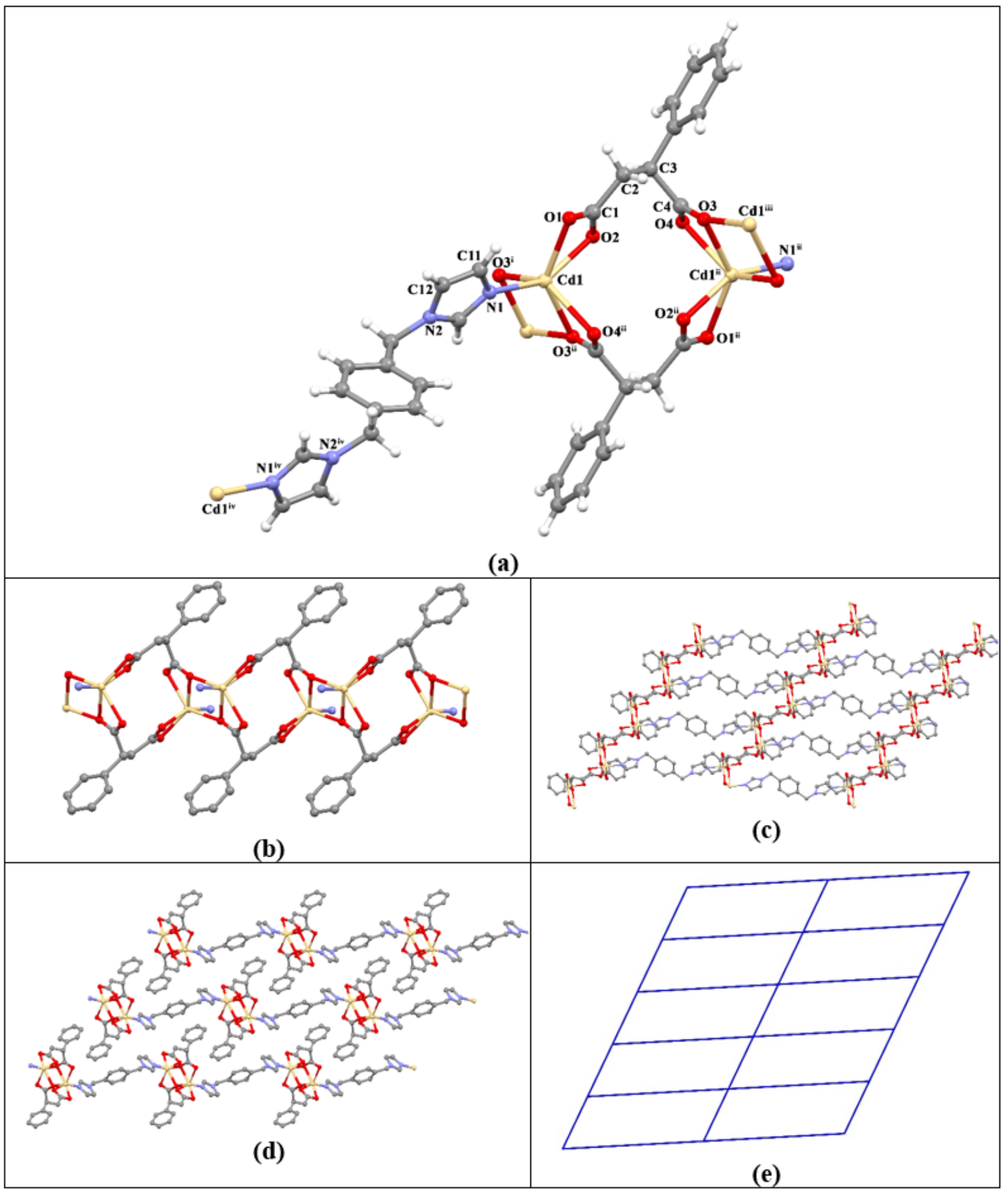

\section{Figure 8}

(a) View of the molecular structure of $\mathbf{8}$ with the atom numbering scheme (b) View of the onedimensional double chain of $\mathbf{8}$ (Hydrogen atoms have been omitted for clarity) (c) View of the twodimensional network of $\mathbf{8}$ (d) View of the 3D supramolecular structure of $\mathbf{8}(\mathbf{e})$ The schematic view of sql topology of 8 ((i) $x+1, y, z$, (ii) $-x,-y+1,-z+1$; (iii) $x-1, y, z$, (iv) $-x+2,-y,-z$ ) 


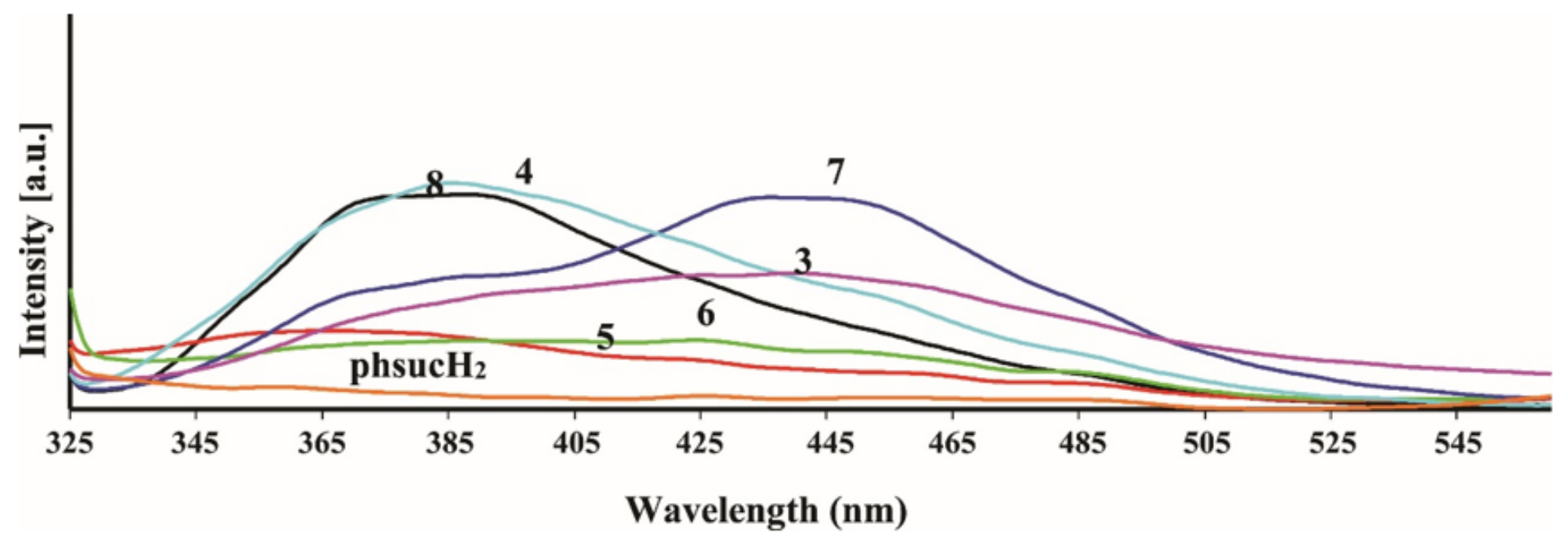

Figure 9

Solid state photoluminescence spectra of $\mathrm{phsucH}_{2}$ and compounds 3-8

\section{Supplementary Files}

This is a list of supplementary files associated with this preprint. Click to download.

- Sl.docx

- Scheme1.png 